\title{
High Prevalence of Novel Beak and Feather Disease Virus in Sympatric Invasive Parakeets Introduced to Spain From Asia and South America
}

\author{
Francisco Morinha ${ }^{1, *(\mathbb{D})}$, Martina Carrete ${ }^{2}$, José L. Tella ${ }^{3} \mathbb{D}$ and Guillermo Blanco ${ }^{1}$ \\ 1 Department of Evolutionary Ecology, National Museum of Natural Sciences (MNCN), Spanish National \\ Research Council (CSIC), José Gutiérrez Abascal 2, 28006 Madrid, Spain; g.blanco@csic.es \\ 2 Department of Physical, Chemical and Natural Systems, University Pablo de Olavide, Ctra. de Utrera km. 1, \\ 41013 Sevilla, Spain; mcarrete@upo.es \\ 3 Department of Conservation Biology, Estación Biológica de Doñana (CSIC), Avda. Américo Vespucio, \\ 41092 Sevilla, Spain; tella@ebd.csic.es \\ * Correspondence: franciscomorinha@hotmail.com or franciscomorinha@mncn.csic.es
}

Received: 26 April 2020; Accepted: 11 May 2020; Published: 13 May 2020

\begin{abstract}
The psittacine beak and feather disease (PBFD) is a globally widespread infectious bird disease that mainly affects species within the Order Psittaciformes (parrots and allies). The disease is caused by an avian circovirus (the beak and feather disease virus, BFDV), which is highly infectious and can lead to severe consequences in wild and captive populations during an outbreak. Both legal and illegal trading have spread the BFDV around the world, although little is known about its prevalence in invasive parrot populations. Here, we analyze the BFDV prevalence in sympatric invasive populations of rose-ringed (Psittacula krameri) and monk parakeets (Myiopsitta monachus) in Southern Spain. We PCR-screened 110 blood samples (55 individuals from each species) for BFDV and characterized the genotypes of five positives from each species. About $33 \%$ of rose-ringed parakeets and $37 \%$ of monk parakeets sampled were positive for BFDV, while neither species showed disease symptoms. The circovirus identified is a novel BFDV genotype common to both species, similar to the BFDV genotypes detected in several parrot species kept in captivity in Saudi Arabia, South Africa and China. Our data evidences the importance of an accurate evaluation of avian diseases in wild populations, since invasive parrots may be bringing BFDV without showing any visually detectable clinical sign. Further research on the BFDV prevalence and transmission (individual-individual, captive-wild and wild-captive) in different bird orders and countries is crucial to understand the dynamics of the viral infection and minimize its impact in captive and wild populations.
\end{abstract}

Keywords: circovirus; PBFD; BFDV; rose-ringed parakeet; monk parakeet; invasive species

\section{Introduction}

Psittacine Beak and Feather Disease (PBFD) is one of the most relevant infectious diseases affecting wild and captive parrot species [1,2]. This disease is caused by the Beak and Feather Disease Virus (BFDV), which is a highly infectious and mutable single-stranded DNA (ssDNA) circovirus [3]. The main PBFD symptoms include feather lesions (loss of feathers, improper moulting, malformations and colour changes) and abnormal growth of the beak, although infected individuals can be asymptomatic [4]. Although information is scarce, the prevalence of BFDV is high in native parrots of Oceania, Africa and Asia [5], including wild populations of some threatened species [6-9]. To our knowledge, no surveillance of BFDV has been conducted on free-living parrots in South America, the other main stronghold for parrots. A screening conducted on captive individuals seized from illegal trade in Brazil showed evidence of BFDV at low prevalence in two native species [10]. The genomic 
similarity of the isolates with reference strains from Asia and Oceania suggested an exotic origin of BFDV strains disseminated in captivity in South America [10,11].

BFDV has been detected in most captive parrot species around the world, showing a high genetic variability, with thousands of genotypes and novel ones described each year $[5,12,13]$. The international legal and illegal trade on captive birds $[14,15]$ has induced a fast spread of BFDV worldwide, a threat that is enhanced in areas where parrots have established invasive populations [16]. Invasive parrot populations can be natural viral hosts, although their role in the genetic diversification of the virus and the spread into native populations of parrots and other avian orders has not yet been explored. However, it has been reported that invasive rose-ringed parakeets (Psittacula krameri) could have been involved in the outbreak of BFDV in the threatened population of Echo parakeets (Psittacula eques) on the island of Mauritius, with devastating effects due to its high mortality rate [2,9]. Moreover, the presence of BFDV has been recently reported in various non-psittacine species, which may both suffer the disease or act as reservoirs, with different prevalences depending on the order [17]. All these aspects increase the epidemiological complexity of the disease and its diagnosis [18], making urgent a comprehensive understanding of its drivers to prevent epidemic outbreaks impacting common but also threatened species.

The rose-ringed parakeet (P. krameri) and the monk parakeet (Myiopsitta monachus) were the first and fourth most traded parrots worldwide [14], and have established exotic populations in various countries around the world mostly as a consequence of accidental escapes of individuals kept as pets [19]. Recent studies have shown that the exotic populations of these two species mainly originated from individuals traded from India and an area between Argentina and Uruguay, respectively [20-22]. Governmental and environmental organizations have applied different measures to control these populations [23-25], highlighting that these invasive birds can be natural reservoirs of infectious bacteria, fungi and viruses of zoonotic concern. However, scientific evidence is scarce [26,27], and only available for rose-ringed parakeets introduced in some European countries [28,29] and on the island of Mauritius [9]. Given the BFDV mutagenic potential and unpredictable viral effects, its study in invasive populations is important to prevent dangerous outbreaks in novel hosts among wild species [9].

Here, we evaluate the prevalence of BFDV in sympatric populations of the invasive rose-ringed parakeet and monk parakeet in Spain and then proceed to its genetic characterization. We reviewed the information on BFDV rep gene isolated from captive rose-ringed parakeets worldwide and assessed whether specific BFDV variants can infect both parrot species despite their different geographic origin. Results are discussed in the context of the global spread of BFDV through wildlife trade and its potential impact on native species of the recipient communities.

\section{Materials and Methods}

From 2015 to 2018, parakeets of both species were captured with mist nets in Sevilla (Southern Spain), where they coexist in urban parks [30]. Individuals were banded, examined for lesions in the beak and plumage alterations, measured for several traits, banded and released. A sample of blood (ca. $0.05 \mathrm{~mL}$ ) was collected from the brachial vein and stored in absolute ethanol for molecular analysis. A random sample of the parakeets (55 individuals from each species) was screened for the presence of BFDV ( $n=17,16,12,10$ in 2015-2018 for P. krameri; $n=25,13,17$ in 2016-2018 for M. monachus). The capture and extraction of blood samples from parakeets were approved by the Ethical Committee of EBD-CSIC (our national research institution), codes: 11_27-Tella and 12_48-Tella.

The DNA was isolated from blood using the Quick-DNA Miniprep Kit (Zymo Research) using an optimized protocol (i.e., samples were digested at $56^{\circ} \mathrm{C}$ for $12 \mathrm{~h}$ in a solution containing $200 \mu \mathrm{L}$ of genomic lysis buffer and $20 \mu \mathrm{L}$ of $20-\mathrm{mg} / \mathrm{mL}$ proteinase $\mathrm{K})$. The screening of BFDV was performed on all samples using two primer sets (5'-AACCCTACAGACGGCGAG-3' and 5'-GTCACAGTCCTCCTTGTACC-3', [31]; 5'-TTAACAACCCTACAGACGGCGA-3' and 5'-GGCGGAGCATCTCGCAATAAG-3', [32]) that amplify a partial sequence of the replication-associated protein (rep) gene. PCR was performed in a reaction mixture of $20 \mu \mathrm{L}$ containing $10 \mu \mathrm{L}$ of $2 x$ MyTaq HS Mix (Bioline), $250 \mathrm{nM}$ of each primer 
(final concentration) and $\sim 20 \mathrm{ng}$ of template DNA. The amplification protocol was composed of the following steps: $95^{\circ} \mathrm{C}$ for $5 \mathrm{~min}$ followed by 40 cycles of $95^{\circ} \mathrm{C}$ for $30 \mathrm{~s}, 58^{\circ} \mathrm{C}$ for $1 \mathrm{~min}, 72^{\circ} \mathrm{C}$ for $30 \mathrm{~s}$, and a final extension at $60^{\circ} \mathrm{C}$ for $10 \mathrm{~min}$. Negative controls and non-template controls were used in all PCR reactions to exclude contamination issues. Population-prevalence estimates and $95 \% \mathrm{CI}$ were calculated with Epitools [33] following Fogell et al. [16].

Samples were considered BFDV positive if at least one primer pair PCR had an accurate amplification of the expected size fragment. Five random positive samples of each species were bi-directionally sequenced by Sanger sequencing to assess genotype diversity. Sequences were visualized and edited using the software Geneious v.11.1.5. Then, our sequences were compared with data available in GenBank through a BLAST search [34]. The program BEAST v.2.6.0 [35] was used to construct a Maximum Clade Credibility (MCC) tree using the 100 sequences most related with the genotype characterized in this study. These sequences were obtained through a BLAST search and covered a total of 77 BFDV genotypes (see Supplementary database 1). The model of sequence evolution HKY + I + G4 was selected after careful estimation of this evolutionary parameter with jModelTest v.2.1.7 [36]. The proportion of invariable sites was set to 0.491 and the alpha shape parameter $(\alpha)$ was set to 0.643 , using a normal distribution for the rate prior and letting the program to estimate the mutation rates. The strict clock and Yule model priors were used. The software run consisted of 200 million steps, with a sampling of the chains every 20,000 steps and a burn-in of $10 \%$. The adequate convergence and mixing of the chains and sufficient effective sample sizes (ESS) were checked with Tracer v.1.7.1 [37]. The consensus tree was visualized and edited using the software FigTree v.1.4.4 [38]. The same procedures (changing only the model of evolution to HKY + G4 using $\alpha=0.115$ ) were used to construct an MCC tree using only P. krameri rep gene sequences with a $100 \%$ coverage of the query sequence in the BLAST search.

\section{Results}

A similar prevalence of BFDV was found in both species (rose-ringed parakeet: 18 of $55,32.7 \%$, 95\% CI: 21.8-45.9; monk parakeet: 20 of 55, 36.4\%, 95\% CI: 24.9-49.6; Fisher's exact test, $p=0.84$ ). Individuals positive to BFDV were found in $2016(50.0 \%, n=16)$ and $2017(83.3 \%, n=12)$ but not in $2015(0.0 \%, n=17)$ and $2018(0.0 \%, n=10)$ for P. krameri. BFDV-positive samples were found in all sampling years for M. monachus (2016, 24.0\%, $n=25 ; 2017,38.5 \%, n=13 ; 2018,52.9 \%, n=17)$. No individual showed visible signs of the disease.

The partial sequence of the rep gene isolated and characterized for rose-ringed parakeets and monk parakeets revealed a novel and unique BFDV genotype common to both species (GenBank accessions: MT303063 and MT303064). Our analysis indicates that the novel genotype differed by nine to 13 nucleotide substitutions with the most similar genotypes among all BFDV sequences described to date for different psittacine species (Figure 1). These closest variants were found in captive individuals of several parrot species (P. krameri, Psittacus erithacus, Nymphicus hollandicus, Agapornis fischeri and Poicephalus gulielmi) in Saudi Arabia, China and South Africa (Figure 1). Phylogenetic data suggest that genotypes isolated in Saudi Arabia and South Africa diverged from the novel circovirus genotype found in Spain (Figure 1). The phylogeny of the rep sequences isolated from P. krameri in various countries supports the proximity of the BFDV genotypes isolated from wild individuals in an invasive population in Spain with captive individuals in Saudi Arabia, which share an ancestor with the two genotypes also detected in captive individuals in Poland (Figure 2). 


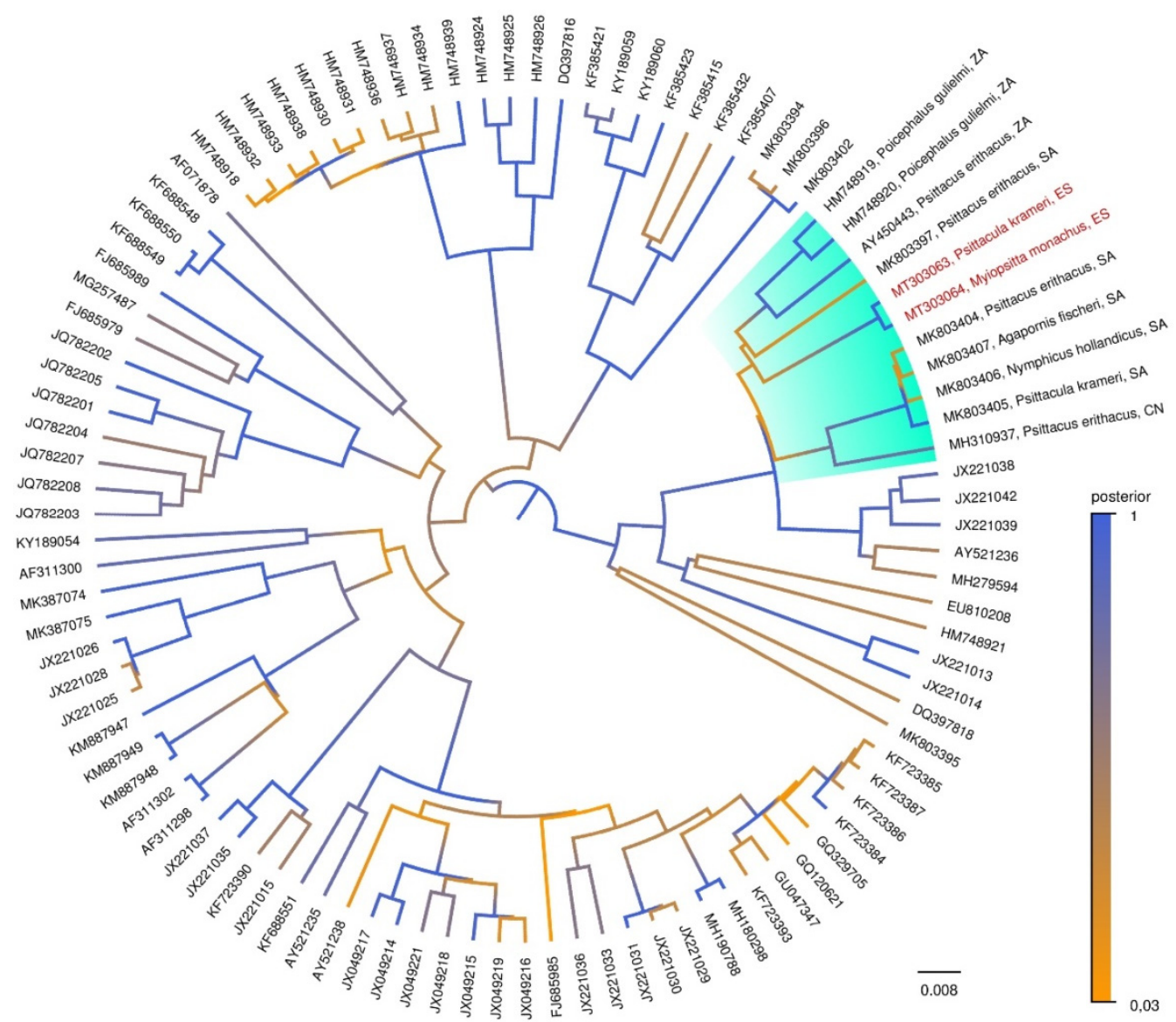

Figure 1. Maximum Clade Credibility tree for the beak and feather disease virus (BFDV) rep gene partial nucleotide sequences (603 bases). Posterior probabilities for the nodes are represented with a colour gradient scale. All partial rep sequences are identified by GenBank accession number. The clade that includes the novel circovirus genotype is highlighted and also shows species and country codes (ISO 3166-1 alpha-2). The detailed list of host species, country of virus isolation and genotypes are presented as supplementary database 1 .

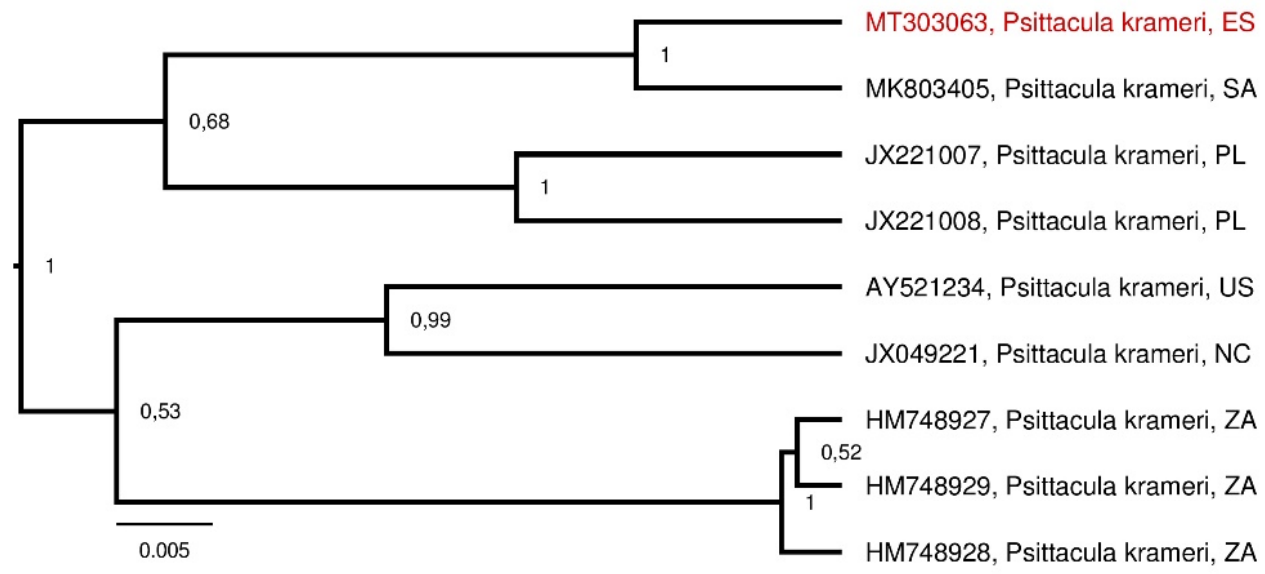

Figure 2. Maximum clade credibility tree inferred using partial nucleotide sequences of the BFDV rep gene isolated from rose-ringed parakeets (Psittacula krameri). Posterior probabilities are indicated for each node. All partial rep sequences are defined by GenBank accession number, species and country codes (ISO 3166-1 alpha-2). The novel circovirus genotype of Spain (ES) is highlighted. 
The partial BFDV sequences isolated from rose-ringed parakeets in Spain and Saudi Arabia differ in $9(1.5 \%)$ nucleotides and $1(0.5 \%)$ amino acid (Table 1$)$. However, the pattern of nucleotide and amino acid variations between isolates from different countries and continents is extreme, ranging from nine $(1.5 \%)$ to $49(8.1 \%)$ nucleotides and from zero to $16(8.0 \%)$ amino acids (Table 1$)$.

Table 1. Number of nucleotide (below diagonal) and amino acid (above diagonal) variations between partial sequences of the BFDV rep gene isolated from rose-ringed parakeets (Psittacula krameri). The percentage of variation considering the sequence length (603 nucleotides and 201 amino acids) is noted in parentheses.

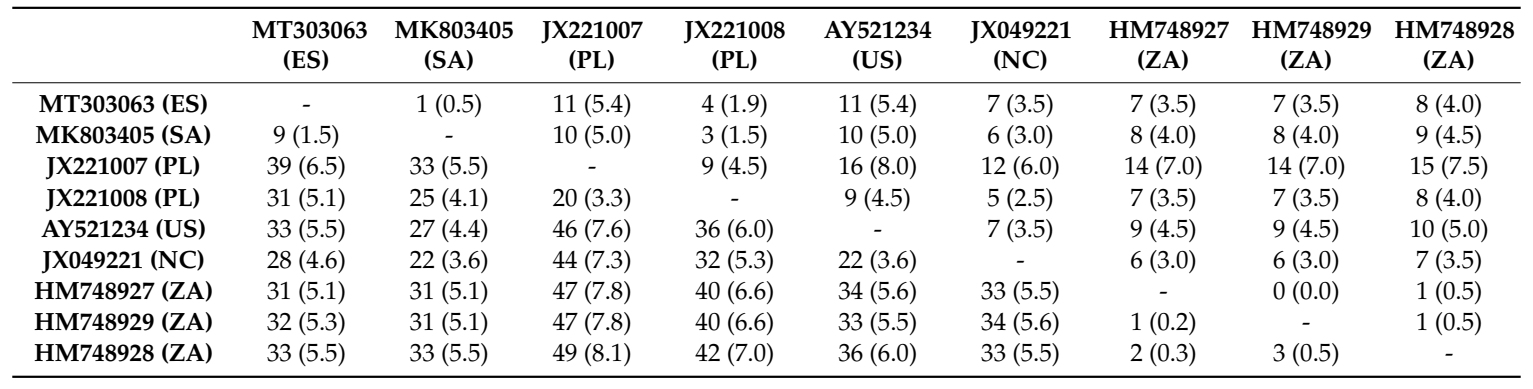

\section{Discussion}

Our study revealed a high prevalence of BFDV in the two sympatric invasive populations of rose-ringed parakeets and monk parakeets sampled in Southern Spain. No individual showed visible signs of the disease, which suggests that most of them were asymptomatic carriers or that ill (i.e., symptomatic) individuals die soon because of the disease $[4,8,9]$ or are rapidly eliminated from the wild by natural selection [39]. The high prevalence of BFDV in the rose-ringed parakeet contrasts with the very low values in blood reported for other invasive populations of this species in Europe, Asia and Africa (from $0.0 \%$ in Germany [29] to 16.1\% in Mauritius [16]). These values were lower than those reported in native populations in Asia (100\% in Bangladesh and 71.4\% in Pakistan [16]). It is worth mentioning that prevalence detected in our study area are similar to those found in native species from Australia and New Zealand, where the BFDV is endemic [40-42]. Differences in prevalence can be real among populations, although they can also arise due to the tissue analysed and to the selection of primers [16]. In our case, following previous studies showing high variability in the amplification specificity and sensitivity between different primers sets [43], we used two different sets of primers to search for BFDV. Positive samples for the virus only amplified with the primers reported by Ritchie et al. [32], likely due to variations in viral copy numbers or mutations in the primer binding sites in some BFDV genotypes. However, several studies only focused on one primer set for BFDV screening [10,12,17], and thus may have underestimated the actual prevalence in these populations. Further research using different molecular markers is thus needed to increase the robustness of the BFDV diagnosis test.

The evidence of BFDV infections in monk parakeets is restricted to a presumed case reporting beak lesions in a Greek invasive population, although no genetic, microbiological or other type of validation was provided [44]. No further information is available in its native or invasive range, so this is the first estimate of prevalence of BFDV in this species in the wild.

Genotype variations are frequent in circovirus and there are thousands of BFDV genotypes described and available through genome browsers $[5,12,13]$. This variability may explain species-specific susceptibility and infection impact, which deserves further research on the potential infectiousness to native species in the invasive range of these parakeet species. The novel genotype characterized in this study and its closest viral variants can colonize psittacids from all continents. This has important implications for the spread of this and other viral variants on native parrots interacting with invasive ones [9] or with individuals escaped from captivity, especially in the Neotropics where many parrot species are of conservation concern [45]. 
Phylogenetic data suggest that genotypes isolated in Saudi Arabia and South Africa diverged from the novel circovirus genotype found in Spain, which share an ancestor with the two genotypes also detected in captive individuals in Poland. These countries imported and exported thousands of captive-bred and wild parrots (and other birds) from and towards Spain and other European countries in recent decades according to CITES Trade Database [46]. This result highlights the potential role played by the international bird trade in the spread of wildlife infectious diseases and the emergence of zoonosis $[8,47,48]$. Specifically, the capacity of the same circovirus variant to colonize different parrot species, one a native of Asia and the other from South America, in one area of their European invasive range emphasizes the complex and concerning outcomes of trade-driven biological invasions on the global circulations of pathogens.

Invasive parrot populations with high prevalence of BFDV are not only of concern in areas of coexistence with other parrot species. There is evidence that BFDV can be transmitted from native parrots to several avian species of different orders [17], with some individuals showing the typical beak and plumage alterations of this disease [43,49]. A previous study showed BFDV symptoms and the presence of the causative virus in captive Gouldian finches (Chloebia gouldiae), which were suggested to be infected by invasive monk parakeets in Italy [50]. However, no test of the occurrence of the virus in the parakeets was conducted. Thus, the high prevalence of BFDV in the invasive parakeet populations sampled in southern Spain should be carefully considered, as it may have important consequences for the conservation of native birds, particularly those sharing habitats or nests with these invasive species and those predating on them both in urban and rural habitats [30,51,52]. These concerns increase due to the fast spread rates of these two parakeet species in Spain $[19,53]$.

\section{Conclusions}

We show a high prevalence of a novel BFDV in free-ranging, sympatric invasive populations of two parakeets native to different continents in Southern Spain. Although previous studies have demonstrated the presence of BFDV in rose-ringed parakeets, this is the first genetic evidence of BFDV in monk parakeets. Both legal and illegal trade can contribute considerably to the dissemination of the virus in non-endemic regions, which can have important impacts not yet considered on native birds [54]. Thus, surveillance of invasive populations should be mandatory taking into account the high mutation rate of the virus and the possible cross-transmission to native species. We strongly encourage a strict control or total ban on the international bird trade to avoid the spread of this and other pathogens potentially threatening wildlife and public health.

Supplementary Materials: The following are available online at http://www.mdpi.com/1424-2818/12/5/192/s1, Database 1: detailed list of GenBank accessions, host species, country of virus isolation and genotypes of the BFDV rep gene.

Author Contributions: Conceptualization, F.M., M.C., J.L.T., and G.B.; methodology, F.M., M.C., J.L.T., and G.B.; software, F.M.; validation, F.M.; formal analysis, F.M.; investigation, F.M., M.C., J.L.T., and G.B.; resources, F.M., M.C., and J.L.T.; data curation, F.M.; writing-original draft preparation, F.M., and G.B.; writing-review and editing, F.M., M.C., J.L.T., and G.B.; visualization, F.M., M.C., J.L.T., and G.B.; supervision, F.M., M.C., J.L.T., and G.B.; project administration, M.C., and J.L.T.; funding acquisition, M.C., and J.L.T. All authors have read and agreed to the published version of the manuscript.

Funding: F.M. was supported by a Juan de la Cierva postdoctoral fellowship from Spain's Ministry of Science and Innovation (FJCI-2017-32055). This work was partially supported by Loro Parque Fundación.

Acknowledgments: Logistic and technical support for laboratory and field work was provided by Doñana ICTS-RBD. We thank Centro Andaluz de Arte Contemporáneo for allowing us to capture parakeets within its urban gardens, and to Simon Young for editing the English.

Conflicts of Interest: The authors declare no conflict of interest. 


\section{References}

1. Fogell, D.J.; Martin, R.O.; Groombridge, J.J. Beak and feather disease virus in wild and captive parrots: An analysis of geographic and taxonomic distribution and methodological trends. Arch. Virol. 2016, 161, 2059-2074. [CrossRef]

2. Raidal, S.R.; Peters, A. Psittacine beak and feather disease: Ecology and implications for conservation. Emu 2018, 118, 80-93. [CrossRef]

3. Sarker, S.; Patterson, E.I.; Peters, A.; Baker, G.B.; Forwood, J.K.; Ghorashi, S.A.; Holdsworth, M.; Baker, R.; Murray, N.; Raidal, S.R. Mutability dynamics of an emergent single stranded DNA virus in a naïve host. PLoS ONE 2014, 9, e85370. [CrossRef] [PubMed]

4. Pass, D.A.; Perry, R.A. The pathology of psittacine beak and feather disease. Aust. Vet. J. 1984, 61, 69-74. [CrossRef]

5. Harkins, G.W.; Martin, D.P.; Christoffels, A.; Varsani, A. Towards inferring the global movement of beak and feather disease virus. Virology 2014, 450, 24-33. [CrossRef]

6. Warburton, L.; Perrin, M. Evidence of psittacine beak and feather disease in wild Black-cheeked Lovebirds in Zambia. Papageien 2002, 5, 166-169.

7. Regnard, G.L.; Boyes, R.S.; Martin, R.O.; Hitzeroth, I.I.; Rybicki, E.P. Beak and feather disease viruses circulating in Cape parrots (Poicepahlus robustus) in South Africa. Arch. Virol. 2015, 160, 47-54. [CrossRef] [PubMed]

8. Fogell, D.J.; Groombridge, J.J.; Tollington, S.; Canessa, S.; Henshaw, S.; Zuel, N.; Jones, C.G.; Andrew Greenwood, A.; Ewen, J.G. Hygiene and biosecurity protocols reduce infection prevalence but do not improve fledging success in an endangered parrot. Sci. Rep. 2019, 9, 1-10. [CrossRef] [PubMed]

9. Kundu, S.; Faulkes, C.G.; Greenwood, A.G.; Jones, C.G.; Kaiser, P.; Lyne, O.D.; Black, S.A.; Aurelie Chowrimootoo, A.; Groombridge, J.J. Tracking viral evolution during a disease outbreak: The rapid and complete selective sweep of a circovirus in the endangered Echo parakeet. J. Virol. 2012, 86, 5221-5229. [CrossRef] [PubMed]

10. Araújo, A.V.; Andery, D.A.; Ferreira, F.C., Jr.; Ortiz, M.C.; Marques, M.V.R.; Marin, S.Y.; Vilela, D.A.R.; Resende, J.S.; Resende, M.; Donatti, R.V.; et al. Molecular diagnosis of beak and feather disease in native Brazilian psittacines. Braz. J. Poult. Sci. 2015, 17, 451-458. [CrossRef]

11. González-Hein, G.; Gil, I.A.; Sanchez, R.; Huaracan, B. Prevalence of Aves Polyomavirus 1 and Beak and Feather Disease Virus From Exotic Captive Psittacine Birds in Chile. J. Avian Med. Surg. 2019, 33, 141-149. [CrossRef] [PubMed]

12. Massaro, M.; Ortiz-Catedral, L.; Julian, L.; Galbraith, J.; Kurenbach, B.; Kearvell, J.; Kemp, J.; Hal, J.; Elkington, S.; Taylor, G.; et al. Molecular characterisation of beak and feather disease virus (BFDV) in New Zealand and its implications for managing an infectious disease. Arch. Virol. 2012, 157, 1651-1663. [CrossRef] [PubMed]

13. Varsani, A.; Regnard, G.L.; Bragg, R.; Hitzeroth, I.I.; Rybicki, E.P. Global genetic diversity and geographical and host-species distribution of beak and feather disease virus isolates. J. Gen. Virol. 2011, 92, 752-767. [CrossRef] [PubMed]

14. Cardador, L.; Lattuada, M.; Strubbe, D.; Tella, J.L.; Reino, L.; Figueira, R.; Carrete, M. Regional bans on wild-bird trade modify invasion risks at a global scale. Conserv. Lett. 2017, 10, 717-725. [CrossRef]

15. Ribeiro, J.; Reino, L.; Schindler, S.; Strubbe, D.; Vall-llosera, M.; Bastos Araújo, M.; Capinha, C.; Carrete, M.; Mazzoni, S.; Monteiro, M.; et al. Trends in legal and illegal trade of wild birds: A global assessment based on expert knowledge. Biodivers. Conserv. 2019, 28, 3343-3369. [CrossRef]

16. Fogell, D.J.; Martin, R.O.; Bunbury, N.; Lawson, B.; Sells, J.; McKeand, A.M.; Tatayah, V.; Trung, C.T.; Groombridge, J.J. Trade and conservation implications of new beak and feather disease virus detection in native and introduced parrots. Conserv. Biol. 2018, 32, 1325-1335. [CrossRef]

17. Amery-Gale, J.; Marenda, M.S.; Owens, J.; Eden, P.A.; Browning, G.F.; Devlin, J.M. A high prevalence of beak and feather disease virus in non-psittacine Australian birds. J. Med. Microbiol. 2017, 66, 1005-1013. [CrossRef]

18. Rahaus, M.; Wolff, M.H. Psittacine beak and feather disease: A first survey of the distribution of beak and feather disease virus inside the population of captive psittacine birds in Germany. J. Vet. Med. B 2003, 50, 368-371. [CrossRef] 
19. Abellán, P.; Tella, J.L.; Carrete, M.; Cardador, L.; Anadón, J.D. Climatic matching drives spread rate but not establishment success in recent unintentional bird introductions. PNAS 2017, 114, 9385-9390. [CrossRef]

20. Jackson, H.; Strubbe, D.; Tollington, S.; Prys-Jones, R.; Matthysen, E.; Groombridge, J.J. Ancestral origins and invasion pathways in a globally invasive bird correlate with climate and influences from bird trade. Mol. Ecol. 2015, 24, 4269-4285. [CrossRef] [PubMed]

21. Cardador, L.; Carrete, M.; Gallardo, B.; Tella, J.L. Combining trade data and niche modelling improves predictions of the origin and distribution of non-native European populations of a globally invasive species. J. Biogeogr. 2016, 43, 967-978. [CrossRef]

22. Edelaar, P.; Roques, S.; Hobson, E.A.; Gonçalves da Silva, A.; Avery, M.L.; Russello, M.A.; Senar, J.C.; Wright, T.F.; Carrete, M.; Tella, J.L. Shared genetic diversity across the global invasive range of the Monk Parakeet suggests a common restricted geographic origin and the possibility of convergent selection. Mol. Ecol. 2015, 24, 2164-2176. [CrossRef] [PubMed]

23. Kumschick, S.; Blackburn, T.M.; Richardson, D.M. Managing alien bird species: Time to move beyond " 100 of the worst" lists? Bird Conserv. Int. 2016, 26, 154-163. [CrossRef]

24. Avery, M.L.; Shiels, A.B. Monk and rose-ringed parakeets. In Ecology and Management of Terrestrial Vertebrate Invasive Species in the United States, 1st ed.; Pitt, W.C., Beasley, J.C., Witmer, G.W., Eds.; CRC Press: Boca Raton, FL, USA, 2017; pp. 333-358.

25. Nentwig, W.; Bacher, S.; Kumschick, S.; Pyšek, P.; Vilà, M. More than "100 worst" alien species in Europe. Biol. Invasions 2018, 20, 1611-1621. [CrossRef]

26. Mazza, G.; Tricarico, E.; Genovesi, P.; Gherardi, F. Biological invaders are threats to human health: An overview. Ethol. Ecol. Evol. 2014, 26, 112-129. [CrossRef]

27. Mori, E.; Meini, S.; Strubbe, D.; Ancillotto, L.; Sposimo, P.; Menchetti, M. Do alien free-ranging birds affect human health? A global summary of known zoonoses. In Invasive Species and Human Health, 1st ed.; Mazza, G., Tricarcio, E., Eds.; CABI Editions: Wallingford, UK, 2018; pp. 120-129.

28. Sa, R.C.; Cunningham, A.A.; Dagleish, M.P.; Wheelhouse, N.; Pocknell, A.; Borel, N.; Hannah, L.; Peck, H.L.; Lawson, B. Psittacine beak and feather disease in a free-living ring-necked parakeet (Psittacula krameri) in Great Britain. Eur. J. Wildl. Res. 2014, 60, 395-398. [CrossRef]

29. Kessler, S.; Heenemann, K.; Krause, T.; Twietmeyer, S.; Fuchs, J.; Lierz, M.; Corman, V.M.; Vahlenkamp, T.M.; Rubbenstroth, D. Monitoring of free-ranging and captive Psittacula populations in Western Europe for avian bornaviruses, circoviruses and polyomaviruses. Avian Pathol. 2020, 49, 119-130. [CrossRef]

30. Hernández-Brito, D.; Carrete, M.; Popa-Lisseanu, A.; Ibáñez, C.; Tella, J.L. Crowding in the city: Losing and winning competitors of an invasive bird. PLoS ONE 2014, 9, e100593. [CrossRef]

31. Ypelaar, I.; Bassami, M.R.; Wilcox, G.E.; Raidal, S.R. A universal polymerase chain reaction for the detection of psittacine beak and feather disease virus. Vet. Microbiol. 1999, 68, 141-148. [CrossRef]

32. Ritchie, P.A.; Anderson, I.L.; Lambert, D.M. Evidence for specificity of psittacine beak and feather disease viruses among avian hosts. Virology 2003, 306, 109-115. [CrossRef]

33. Sergeant, E. 2018. Epitools Epidemiological Calculators. Ausvet Pty Ltd. Available online: http://epitools. ausvet.com.au/ (accessed on 15 April 2020).

34. Boratyn, G.M.; Camacho, C.; Cooper, P.S.; Coulouris, G.; Fong, A.; Ma, N.; Madden, T.L.; Matten, W.T.; McGinnis, S.D.; Merezhuk, Y. BLAST: A more efficient report with usability improvements. Nucleic Acids Res. 2013, 41, W29-W33. [CrossRef] [PubMed]

35. Bouckaert, R.; Heled, J.; Kühnert, D.; Vaughan, T.; Wu, C.H.; Xie, D.; Suchard, M.A.; Rambaut, A.; Drummond, A.J. BEAST 2: A software platform for Bayesian evolutionary analysis. PLoS Comput. Biol. 2014, 10, e1003537. [CrossRef] [PubMed]

36. Darriba, D.; Taboada, G.L.; Doallo, R.; Posada, D. jModelTest 2: More models, new heuristics and parallel computing. Nat. Methods 2012, 9, 772. [CrossRef] [PubMed]

37. Rambaut, A.; Drummond, A.J.; Xie, D.; Baele, G.; Suchard, M.A. Posterior summarization in Bayesian phylogenetics using Tracer 1.7. Syst. Biol. 2018, 67, 901-904. [CrossRef] [PubMed]

38. Rambaut, A. Figtree Software (v.1.4.4). 2018. Available online: http://tree.bio.ed.ac.uk/software/figtree/ (accessed on 20 February 2020).

39. Genovart, M.; Negre, N.; Tavecchia, G.; Bistuer, A.; Parpal, L.; Oro, D. The young, the weak and the sick: Evidence of natural selection by predation. PLoS ONE 2010, 5, e9774. [CrossRef] [PubMed] 
40. Ha, H.J.; Anderson, I.L.; Alley, M.R.; Springett, B.P.; Gartrell, B.D. The prevalence of beak and feather disease virus infection in wild populations of parrots and cockatoos in New Zealand. N. Z. Vet. J. 2007, 55, 235-238. [CrossRef]

41. Ortiz-Catedral, L.; McInnes, K.; Hauber, M.E.; Brunton, D.H. First report of beak and feather disease virus (BFDV) in wild Red-fronted Parakeets (Cyanoramphus novaezelandiae) in New Zealand. Emu 2009, 109, $244-247$. [CrossRef]

42. Eastwood, J.R.; Berg, M.L.; Ribot, R.F.; Buchanan, K.L.; Walder, K.; Bennett, A.T. Prevalence of BFDV in wild breeding Platycercus elegans. J. Ornithol. 2019, 160, 557-565. [CrossRef]

43. Sarker, S.; Moylan, K.G.; Ghorashi, S.A.; Forwood, J.K.; Peters, A.; Raidal, S.R. Evidence of a deep viral host switch event with beak and feather disease virus infection in rainbow bee-eaters (Merops ornatus). Sci. Rep. 2015, 5, 14511. [CrossRef]

44. Kalodimos, N. First account of a nesting population of Monk parakeets (Myiopsitta monachus) with nodule-shaped bill lesions in Katehaki, Athens, Greece. Bird Popul. 2013, 12, 1-6.

45. Berkunsky, I.; Quillfeldt, P.; Brightsmith, D.J.; Abbud, M.C.; Aguilar, J.M.R.E.; Alemán, U.; Aramburú, R.M.; Arce Arias, A.; Balas McNab, R.; Balsby, T.J.S.; et al. Current threats faced by Neotropical parrot populations. Biol. Conserv. 2017, 214, 278-287. [CrossRef]

46. CITES Trade Database. Available online: https://trade.cites.org/ (accessed on 10 April 2020).

47. Fèvre, E.M.; Bronsvoort, B.M.D.C.; Hamilton, K.A.; Cleaveland, S. Animal movements and the spread of infectious diseases. Trends Microbiol. 2006, 14, 125-131. [CrossRef] [PubMed]

48. Menchetti, M.; Mori, E. Worldwide impact of alien parrots (Aves Psittaciformes) on native biodiversity and environment: A review. Ethol. Ecol. Evol. 2014, 26, 172-194. [CrossRef]

49. Sarker, S.; Lloyd, C.; Forwood, J.; Raidal, S.R. Forensic genetic evidence of beak and feather disease virus infection in a powerful owl (Ninox strenua). Еmu 2016, 116, 71-74. [CrossRef]

50. Circella, E.; Legretto, M.; Pugliese, N.; Caroli, A.; Bozzo, G.; Accogli, G.; Lavazza, A.; Camarda, A. Psittacine Beak and Feather Disease-like Illness in Gouldian Finches (Chloebia gouldiae). Avian Dis. 2014, 58, $482-487$. [CrossRef] [PubMed]

51. Mori, E.; Malfatti, L.; Le Louarn, M.; Brito, D.H.; Ten Cate, B.; Ricci, M.; Menchetti, M. 'Some like it alien': Predation on invasive ring-necked parakeets by the long-eared owl in an urban area. Anim. Biodiv. Conserv. 2020, 43, 151-158.

52. Hernández-Brito, D.; Blanco, G.; Tella, J.L.; Carrete, M.A. protective nesting association with native species counteracts biotic resistance for the spread of an invasive parakeet from urban to rural habitats. Front. Zool. 2020, 17, 1-13. [CrossRef]

53. Abellán, P.; Carrete, M.; Anadón, J.D.; Cardador, L.; Tella, J.L. Non-random patterns and temporal trends (1912-2012) in the transport, introduction and establishment of exotic birds in Spain and Portugal. Divers. Distrib. 2016, 22, 263-273. [CrossRef]

54. Turbé, A.; Strubbe, D.; Mori, E.; Carrete, M.; Chiron, F.; Clergeau, P.; González-Moreno, P.; Le Louarn, M.; Luna, A.; Menchetti, M.; et al. Assessing the assessments: Evaluation of four impact assessment protocols for invasive alien species. Divers. Distrib. 2017, 23, 297-307. [CrossRef]

(C) 2020 by the authors. Licensee MDPI, Basel, Switzerland. This article is an open access article distributed under the terms and conditions of the Creative Commons Attribution (CC BY) license (http://creativecommons.org/licenses/by/4.0/). 